\title{
A new source for developing multi-functional products: biological and chemical perspectives on subcritical water extracts of Sambucus ebulus L.
}

\author{
Aleksandra Cvetanović, ${ }^{\text {a }}$ Zoran Zeković, ${ }^{a}$ Jaroslava Švarc-Gajić, ${ }^{a}$ Slavica \\ Razić, ${ }^{b}$ Ana Damjanović, ${ }^{c}$ Gokhan Zengin, ${ }^{d}$ Cristina Delerue-Matos ${ }^{\mathrm{e}}$ and \\ Manuela Moreirae
}

\begin{abstract}
BACKGROUND: To obtain bioactive fractions from plant material subcritical water is notably advantageous in comparison to any other technique. Excellent solvating properties and selectivity combined with finely tuned reactivity of subcritical water enable exploitation of the potential of plants. Herein subcritical water extraction was used for recovery of bioactive compounds from leaves, roots and fruits of Sambucus ebulus L. Extracts obtained were characterized in terms of biological and chemical fingerprints.

RESULTS AND DISCUSSION: Results obtained by using several antioxidant assays that focused on different mechanisms showed that subcritical water extracts of Sambucus ebulus were powerful antioxidants. Enzyme inhibitory effects were tested against $\alpha$-amylase, $\alpha$-glucosidase and tyrosinase, and the results showed the anti-diabetic potential of the extracts as well as its possible use with skin disorders. Antiproliferative properties were detected on three cell lines (A-549; LS-174 T; HeLa) and showed prominent cytotoxicity against all tumor cell lines. Inhibitory concentrations obtained were in the range $0.58-8.10 \mu \mathrm{g} \mathrm{mL} \mathrm{L}^{-1}$. Generally, the SCW extracts from leaves exhibited stronger biological activities with higher levels of phenolic compounds compared with the roots and fruits of Sambucus ebulus. Gallic acid, catechin and caffeic acid were identified as major components in these extracts and these components seem to relate with observed biological activity.
\end{abstract}

CONCLUSION: The results obtained suggest that Sambucus ebulus has great potential for preparing new phyto-pharmaceuticals and functional food ingredients.

Keywords: extraction; pharmaceuticals; supercritical -uids; subcritical water extraction; plant

\section{INTRODUCTION}

The plant kingdom has served as one of the oldest sources of useful drugs, and contemporary science has expressed a growing interest in plants as a vehicle to discover and manufacture drugs. Indeed, the contribution of plants to disease treatment and prevention is still enormous despite the current preoccupation with synthetic chemistry. In addition, natural products and compounds are suitable for the subsequent design of structurally related molecules that are more active or less toxic. ${ }^{1}$ Among different plants special attention has been given to plants, well-known in folk medicine. One of those plants, whose application was reported in 'Natural History' of Pliny the Elder (23-79 CE), is Sambucus ebulus L. (Adoxacea), or dwarf elder. This perennial herbaceous plant is a popular medical herb with a prominent place in the folk medicine of the people from the Balkan Peninsula, Western Europe, and Middle East. Different parts of this plant were traditionally administered in human medicine to treat bites, burns, infectious wounds, edema, eczema, urticaria, arthritis and sore-throat. ${ }^{2-7}$ Raw fruits have also been used for wound healing. ${ }^{8}$ In a study on various medicinal plants from Bulgaria, this plant was found to be the second richest plant in polyphenols and antioxidant activity. ${ }^{9}$ On the other hand, berries of this plant contain lectins which may be anti-nutrients and toxic. ${ }^{10,11}$ However, no scientifically sound data are available on elder toxicity. ${ }^{12}$

\footnotetext{
Correspondence to: A Cvetanović, Faculty of Technology, Bulevar Cara Lazara 1,21000 Novi Sad, Serbia.Email:a.c.istrazivac@gmail.com

a Faculty of Technology, Novi Sad, Serbia

b Faculty of Pharmacy, Belgrade, Serbia

c Department for Experimental Oncology, Institute of Oncology and Radiology of Serbia, Belgrade, Serbia

d Department of Biology, Selcuk University, Konya, Turkey

e REQUIMTE/LAQV, Instituto Superior de Engenharia do Instituto Politécnico do Porto, Porto, Portugal
} 
Due to this richness in biological active compounds, it is essential to prepare extracts with high concentration of such compounds and with low amounts of interfering substances. For this purposes different extraction approaches could be applied. According to the literature data, extraction of Sambucus ebulus was performed by macerations using hexane, methanol, ethyl acetate, acetone or petroleum ether. ${ }^{13-15}$ However, these solvents are toxic and for that reason not applicable for oral use. This is in collision with the desire to make completely natural and safe products. For this reason, development of new technologies that comply with strict environmental requirements are the focus of numerous scientific studies. Subcritical water (SCW) extraction represents an innovative 'green' technology of exceptional potential. This environmentally-benign technology is particularly popular for extraction and isolation of biologically active compounds from plants.

Basically, SCW is hot water at temperatures above boiling and below its critical point while maintaining high pressures in order to keep the water in the liquid state. ${ }^{16}$ These conditions change some physicochemical properties of water, influencing its solvating properties. Namely, heating decreases the viscosity, density and surface tension of water contributing to extraction efficiency. Furthermore, the increase in temperature improves mass transfer as a result of lower water surface tension that allows better penetration into the sample matrix. In addition, the mass transfer kinetics is favored by the disruption of intermolecular forces (i.e. van der Waals forces, hydrogen bonds and dipole attractions) in the sample matrix. However, the most important effects of the increase in liquid water temperature are the weakening of hydrogen bonds, resulting in a lower dielectric constant. ${ }^{17-20}$ More precisely, by heating, the dielectric constant of water can be drastically changed, e.g. increasing the temperature from $25^{\circ} \mathrm{C}$ to $300^{\circ} \mathrm{C}$ reduces its values from 80 to almost 20 . Thus, decreased polarity produces a solvent with good solvating properties for moderately polar compounds. For these reasons water can be used as a low-cost solvent for the extraction of moderately polar and even non-polar analytes, under specific experimental conditions. ${ }^{21}$ On the other hand, due to the high extraction temperature, degradation of thermolabile analytes could occur. There are several publications about degradation of phenolic compounds in subcritical water. ${ }^{22-24}$ Thus, the effects of temperature on stability of the analytes should be taken into consideration in method development. ${ }^{16}$

The purpose of this study was to investigate the chemical composition and biological activity of Sambucus ebulus extracts and to explore the possibility of isolating biologically active compounds from Sambucus ebulus by an absolutely 'green' extraction method. Taking into account that heat treatment can lead to denaturation of ebulin, toxic lectin naturally present in this plant, SCW extraction offers possibilities to eliminate the toxicity of this lectin along with maintaining high biological activity of the extracts. Thus, this study demonstrates the feasibility of technologies based on SCW to obtain plant-derived products to increase their functionality and value. Sambucus ebulus extracts could be considered as a potential candidate for designing new functional food ingredients. Moreover, there are no data in the literature on the anti-cancer activity of this plant, and also the possibility to use this plant for inhibition of particular enzymes is unknown. Thus this study represents the first attempt to explore such activity of Sambucus ebulus extracts and to explore the polyphenolic content of different plant parts.

\section{MATERIALS AND METHODS}

\section{Chemicals and reagents}

Folin-Ciocalteu reagent, 1,1-diphenyl-2-picryl-hydrazyl-hydrate (DPPH), $\alpha$-amylase solution (ex-porcine pancreas, EC 3.2.1.1), $\alpha$-glucosidase solution (from Saccharomyces cerevisiae, EC 3.2.1.20), L-glutathione, tyrosinase, L-Dopa, kojic acid, acarbose and polyphenolic standards were purchased from Sigma-Aldrich (St. Louis, Missouri, USA). Aluminium chloride hexahydrate, sodium carbonate, PNPG (4-N-trophenyl- $\alpha$-D-glucopyranoside), and sodium acetate trihydrate were purchased from Merck (Darmstadt, Germany). Acetonitrile and acetic acid (both of MS grade), methanol (HPLC grade) were purchased from Merck (Darmstadt, Germany). Ultrapure water (Thermofisher Scientific, Bremen, Germany) was used to prepare standard solutions and blanks. Syringe filters $(13 \mathrm{~mm}$, PTFE membrane $0.45 \mu \mathrm{m})$ were purchased from Supelco (Bellefonte, PA, USA). All other chemicals and reagents were of analytical reagent grade.

\section{Plant material}

Dwarf elder (Sambucus ebulus L.) was collected in the southeast region of Serbia in August 2015. Fruits, leaves and roots of this plant were stacked in a crate with perforated bottom, in order to ensure air flow. Drying was performed naturally on draft in the dark until a moisture content of $10 \%$. Dry plant materials were packed in glass jars and stored in the dark until use.

\section{Sample preparation}

Subcritical water (SCW) extraction was performed in a homemade subcritical water extractor/reactor which is described elsewhere. ${ }^{25}$ Total capacity of the high-pressure stainless steel extraction cell was 1.7 L. Pressurization of the vessel was performed with $99.999 \%$ nitrogen (Messer, Germany). Nitrogen was used in order to prevent oxidation at high temperatures. The operating pressure (40 bar) in the vessel was monitored by in-built manometer. The process temperature $\left(140^{\circ} \mathrm{C}\right)$ was measured by a thermocouple Pt100 and regulated by a temperature controller (Nigos, Serbia, model 1011P). A vibrating platform was used in order to improve mass transfer and prevent local overheating in contact with a heater. Agitation was assured by vibrational movements of the vessel platform at a frequency of $3 \mathrm{~Hz}$. Extraction duration was $30 \mathrm{~min}$. After extraction, the process vessel was immediately cooled in a flow-through water-bath at $20^{\circ} \mathrm{C}$. Depressurization was done by valve opening and purging nitrogen through a valve. Obtained extracts were filtrated and stored in the refrigerator until analysis.

\section{Determination of total phenolic and total flavonoid contents}

The total phenolics content (TPC) in the draft elder extracts was determined by Folin-Ciocalteu procedure ${ }^{26,27}$ using chlorogenic acid as a standard. Absorbance was measured at $750 \mathrm{~nm}$. The content of phenolic compounds was expressed in $\mathrm{mg}$ of chlorogenic acid equivalent (CAE) per $\mathrm{g}$ of plant material $\left(\mathrm{mg} \mathrm{CAE} \mathrm{g}^{-1}\right)$. All experiments were performed in triplicate.

The total flavonoids content (TFC) was determined using aluminum chloride colorimetric assay. ${ }^{28}$ Results were expressed in $\mathrm{mg}$ of rutin equivalent $(\mathrm{RE})$ per $\mathrm{g}$ of dry plant material $\left(\mathrm{mg} \mathrm{RE} \mathrm{g}^{-1}\right)$. All experiments were performed in triplicate.

\section{HPLC analysis}

The phenolics composition of extracts was analyzed using the HPLC method described by Rubilar et al. ${ }^{29}$ with slight modifications. The HPLC system (Shimadzu Corporation, Kyoto, Japan) used 
was equipped with a LC-20 AD prominence pump, a DGU-20AS prominence degasser, a CTO-10AS VP column oven, a SIL-20A HT prominence autosampler, and a SPD-M20A photodiode array detector. Separation of polyphenols was achieved on a Phenomenex Gemini $C_{18}$ column $(250 \mathrm{~mm} \times 4.6 \mathrm{~mm}, 5 \mu \mathrm{m})$ and $a$ guard column with the same characteristics that was kept at $25^{\circ} \mathrm{C}$. The chromatographic conditions were the following: flow rate $1.0 \mathrm{~mL} \mathrm{~min}^{-1}$, sample injection volume of $20 \mu \mathrm{L}$ and mobile phase A (methanol) and mobile phase B (water) both with $0.1 \%$ formic acid. A gradient program was used as follows: $85 \%$ B in 0 min, from $85 \%$ to $70 \%$ B in $20 \mathrm{~min}$, from $70 \%$ to $55 \%$ B in $20 \mathrm{~min}$, from $55 \%$ to $50 \%$ B in $5 \mathrm{~min}$, from $50 \%$ to $45 \%$ B in $5 \mathrm{~min}$, from $45 \%$ to $30 \%$ B in $15 \mathrm{~min}$, from $30 \%$ to $0 \% \mathrm{~B}$ in $10 \mathrm{~min}$, followed by $100 \%$ A for $5 \mathrm{~min}$ and back to $85 \%$ B in 10 min and 10 min of reconditioning before the next injection. The photodiode array detection was conducted by scanning between 190 and $600 \mathrm{~nm}$, and the quantification was conducted at $280 \mathrm{~nm}$ for monomeric flavan-3-ols ((+)- catechin and (-)- epicatechin), for hydroxybenzoic acids (gallic, vanillic, protocatechuic, syringic and $\beta$-resorcylic), naringin, naringenin and cinnamic acid, at $320 \mathrm{~nm}$ for the derivatives of cinnamic acid (caffeic, chlorogenic, $p$-coumaric, ferulic and sinapic), and at $360 \mathrm{~nm}$ for rutin, quercetin and kaempferol. Lab Solutions software (Shimadzu Corporation, Kyoto, Japan) was used for control and data processing. Analytes in each extract were identified by comparing their retention times and UV-VIS spectra with those of standard compounds. Peak purity was checked to exclude any contribution from interfering peaks. The concentrations of individual phenolic compounds in extracts were determined using external standard calibration curves in the concentration range 1 to $50 \mu \mathrm{g} \mathrm{L}^{-1}$ using a mixture of 18 standards. The analytical parameters of the calibration curves were calculated with the Excel program.

\section{DPPH radical scavenging assay}

The antioxidant activity of extracts was tested using the stable 2,2-diphenyl-1-picrylhydrazyl (DPPH) radical. ${ }^{30}$ The extracts were mixed with methanol (96\%) and $90 \mu \mathrm{mol} \mathrm{L}^{-1} \mathrm{DPPH}$ to give final concentrations of $0.01 ; 0.02 ; 0.05 ; 0.1$ and $0.2 \mathrm{mg} \mathrm{mL}^{-1}$. After $60 \mathrm{~min}$ at room temperature, the purple color of the test mixtures turned yellow, due to pairing of the odd electron of the DPPH radical with hydrogen to form the reduced DPPH-H. The resulting decoloration, which is stoichiometric, is proportional to the number of captured electrons. The odd electron in the DPPH radical shows maximum absorption at $515 \mathrm{~nm}$. After measuring the absorbance at that wavelength, the radical scavenging capacity (\%RSC) was calculated using the following equation:

$$
\% R S C=100-\left(A_{\text {sample }} \times 100\right) / A_{\text {blank }}
$$

where: $\mathrm{A}_{\text {sample }}$ is the absorbance of the sample solution and $\mathrm{A}_{\text {blank }}$ is the absorbance of the blank.

This activity was also expressed as inhibitory concentration at $50 \%\left(I C_{50}\right)$, which is the concentration of the test solution to achieve $50 \%$ of the radical scavenging capacity.

\section{Reducing power test}

The reducing power of the extracts was determined according to the method previously described by Oyaizu. ${ }^{31}$ The assay is based on the reduction of $\mathrm{Fe}^{+3}$ by antioxidant compounds. Various concentrations of the extracts $(0.1 ; 0.2 ; 0.3 ; 0.4 ; 0.5,0.6 ; 0.7 ; 0.8 ; 0.9$ and $\left.1 \mathrm{mg} \mathrm{mL}^{-1}\right)$ were mixed with phosphate buffer $(1 \mathrm{~mL}, 0.2 \mathrm{~mol}$ $\left.\mathrm{L}^{-1}, \mathrm{pH} 6.6\right)$ and $1 \mathrm{~mL}$ of $1 \%$ potassium ferricyanide. The mixture was incubated for $20 \mathrm{~min}$ at $50^{\circ} \mathrm{C}$. After incubation, $1 \mathrm{~mL}$ of $10 \%$ trichloroacetic acid solution was added to the mixture. The mixture was further centrifuged at $3000 \mathrm{~min}^{-1}$ for $10 \mathrm{~min}$. The obtained supernatant $(2 \mathrm{~mL})$ was mixed with double distilled water $(2 \mathrm{~mL})$ and $0.1 \% \mathrm{FeCl}_{3}$ solution $(0.4 \mathrm{~mL})$. Absorbance was measured at $700 \mathrm{~nm}$. The blank was prepared by using water instead of an extract. Reducing power ability of the extracts was expressed as $\mathrm{EC}_{50}$ values $\left(\mathrm{mg} \mathrm{mL}^{-1}\right)$, which represents the concentration of extract that gives half-maximum response.

\section{Cytotoxic activity}

Cell lines

For determination of the cytotoxic activity, several cancer cell lines were used: human cervical adenocarcinoma (HeLa), human lung adenocarcinoma (A549), and human colorectal adenocarcinoma (LS 174T). All cell lines were obtained from American Type Culture Collection (Manassas, VA, USA). The cells were maintained in complete nutrient medium RPMI-1640 at $37^{\circ} \mathrm{C}$ in humidified atmosphere with $5 \% \mathrm{CO}_{2} \cdot{ }^{32}$ All reagents were purchased from Sigma-Aldrich (St. Louis, USA).

\section{Treatment of cancer cell lines}

HeLa, A549, LS 174 T were seeded into 96-well microtitre plates (the seeding densities for each cell line were $3000,5000,7000$ cells per well, respectively). $24 \mathrm{~h}$ later five different concentrations of the tested extracts were added to the wells. Control cells were grown in culture medium only.

\section{Determination of cells survival}

After $72 \mathrm{~h}$ incubation, the cells survival was determined by MTT test, as described elsewhere. ${ }^{32-34}$ Briefly, $10 \mu \mathrm{L}$ of MTT solution ( $5 \mathrm{mg} \mathrm{mL}^{-1}$ in phosphate buffered saline) was added to each well. After $4 \mathrm{~h}$ with MTT, $100 \mathrm{~mL}$ of $10 \%$ sodium dodecyl sulfate (SDS) was added to the wells, and the absorbance was measured at $570 \mathrm{~nm}$ the next day. The percentage of cell survivals was calculated according to the procedure described in the literature. ${ }^{32}$ The $\mathrm{IC}_{50}$ was defined as the concentration of the agent that inhibited cell survival by $50 \%$, compared with the vehicle-treated control. Experiments were performed in triplicate and the data are presented as mean value \pm standard deviation (SD). MTT and SDS were products of Sigma-Aldrich (St. Louis, MO, USA).

\section{Enzyme inhibitory activity}

The enzyme inhibitory activity of Sambucus ebulus extracts was evaluated by measuring $\alpha$-amylase, $\alpha$-glucosidase as well as tyrosinase inhibitory activity. $\alpha$-Amylase inhibitory activity was performed using Caraway-Somogyi iodine/potassium iodide (IKI) method. ${ }^{35}$ Sample solution $\left(2 \mathrm{mg} \mathrm{mL}^{-1} ; 25 \mu \mathrm{L}\right.$ ) was mixed with $\alpha$-amylase solution (ex-porcine pancreas, EC 3.2.1.1, Sigma) $(50 \mu \mathrm{L})$ in phosphate buffer (pH6.9 with $6 \mathrm{mmol} \mathrm{L}^{-1}$ sodium chloride) in a 96-well microplate and incubated for $10 \mathrm{~min}$ at $37^{\circ} \mathrm{C}$. After pre-incubation, the reaction was initiated with the addition of starch solution ( $50 \mu \mathrm{L}, 0.05 \%)$. Similarly, a blank was prepared by adding sample solution to all reaction reagents without enzyme ( $\alpha$-amylase) solution. The reaction mixture was incubated for $10 \mathrm{~min}$ at $37^{\circ} \mathrm{C}$. The reaction was then stopped with the addition of $\mathrm{HCl}\left(25 \mu \mathrm{L}, 1 \mathrm{~mol} \mathrm{~L}^{-1}\right)$. This was followed by the addition of iodine-potassium iodide solution $(100 \mu \mathrm{L})$. The sample and blank absorbances were read at $630 \mathrm{~nm}$. The absorbance of the blank was subtracted from that of the sample and the $\alpha$-amylase 
inhibitory activity was expressed as acarbose equivalent (ACE) per $\mathrm{g}$ of dry extract (mmol ACE g $\left.{ }^{-1}\right)$.

$\alpha$-Glucosidase inhibitory activity was performed by the previous method. ${ }^{35}$ Sample solution $\left(2 \mathrm{mg} \mathrm{mL}^{-1} ; 50 \mu \mathrm{L}\right.$ ) was mixed with glutathione (50 $\mu \mathrm{L}$ ), $\alpha$-glucosidase solution (from Saccharomyces cerevisiae, EC 3.2.1.20, Sigma) $(50 \mu \mathrm{L})$ in phosphate buffer ( $\mathrm{pH} 6.8)$ and PNPG (4-N-trophenyl- $\alpha$-D-glucopyranoside) (50 $\mu \mathrm{L}$ ) in a 96-well microplate and incubated for $15 \mathrm{~min}$ at $37^{\circ} \mathrm{C}$. Similarly, a blank was prepared by adding sample solution to all reaction reagents without enzyme ( $\alpha$-glucosidase) solution. The reaction was then stopped with the addition of sodium carbonate $(50 \mu \mathrm{L}, 0.2 \mathrm{~mol}$ $\left.\mathrm{L}^{-1}\right)$. Absorbance of samples and blank was read at $400 \mathrm{~nm}$. The absorbance of the blank was subtracted from that of the sample and the $\alpha$-glucosidase inhibitory activity was expressed as acarbose equivalent (ACE) per $\mathrm{g}$ of dry extract $\left(\mathrm{mmol} \mathrm{ACE} \mathrm{g}^{-1}\right)$.

Tyrosinase inhibitory activity was measured using the modified dopachrome method with L-DOPA as substrate, as previously reported ${ }^{36}$ with slight modifications. Sample solution $\left(2 \mathrm{mg} \mathrm{mL}^{-1}\right.$; $25 \mu \mathrm{L})$ was mixed with tyrosinase solution $(40 \mu \mathrm{L})$ and phosphate buffer (100 $\mu \mathrm{L}, \mathrm{pH} 6.8)$ in a 96-well microplate and incubated for $15 \mathrm{~min}$ at $25^{\circ} \mathrm{C}$. The reaction was then initiated with the addition of L-DOPA ( $40 \mu \mathrm{L}$ ). Similarly, a blank was prepared by adding sample solution to all reaction reagents without enzyme (tyrosinase) solution. The sample and blank absorbances were read at $492 \mathrm{~nm}$ after 10 min of incubation at $25^{\circ} \mathrm{C}$. The absorbance of the blank was subtracted from that of the sample and the tyrosinase inhibitory activity was expressed as kojic acid equivalent (KAE) per $g$ of dry extract (mg KAE g ${ }^{-1}$ ).

\section{Statistical analysis}

Statistical analysis was carried out using a trial version of OriginPro 2015 (OriginLab, Northampton, Massachusetts, USA). For correlation, 2-tailed test of significance was used. All experiments were performed in triplicate, while results are expressed as mean value \pm standard deviation. Levels of significance were as follows: $P<0.1$; $P<0.05$ and $P<0.01$.

\section{RESULTS AND DISSCUSSION}

\section{Polyphenolics composition}

Phenolic substances are assumed to be responsible for the antioxidant activity of plant materials, ${ }^{37}$ but also they are connected with the prevention of cardiovascular diseases, cancers, osteoporosis, neurodegenerative diseases, diabetes mellitus, ${ }^{38-40}$ etc. Figure 1 summarizes the results for contents of total phenols and flavonoids in Sambucus ebulus L. extracts. Phenolic compounds were present in all examined extracts but in different concentrations, depending on plant part. Such distribution of these compounds could be affected by different factors, such as soil composition, the amount of available light, temperature, humidity, or weather conditions. ${ }^{41}$ Furthermore, different strength of bonds between polyphenols and tissues could cause the differences in availability of these compounds from different tissues. The chemical environment in different plant parts has also a strong influence on polyphenolic profile. In that case, selection of suitable extraction methods and conditions is of crucial importance for successful extraction of polyphenols. The results obtained showed that SCW obtained from all three plant parts contain a high amount of these compounds. The content of total phenols was in the range from $37.26 \mathrm{mg} \mathrm{CAE} \mathrm{g}^{-1}$ in root extract to $116.30 \mathrm{mg} \mathrm{CAE} \mathrm{g}^{-1}$ in leaf extract. In the case of total flavonoids the highest amount was detected in extracts prepared from dried leaves $\left(71.33 \mathrm{mg} \mathrm{CAE} \mathrm{g}^{-1}\right)$ which was much

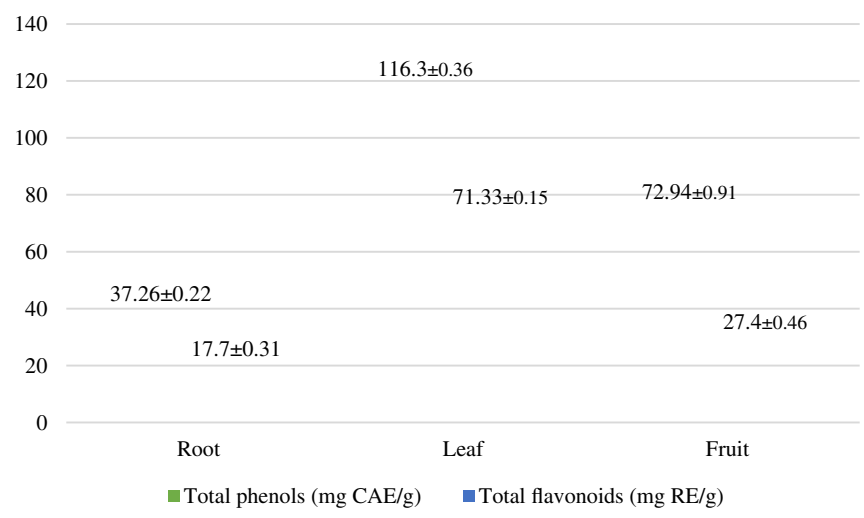

Figure 1. Total phenols and flavonoids content in root, leaf and fruit extracts of Sambucus ebulus L. subcritical water extracts.

higher content than in the fruit $\left(27.4 \mathrm{mg} \mathrm{CAE} \mathrm{g}^{-1}\right)$ and root $(17.7 \mathrm{mg}$ CAE $\mathrm{g}^{-1}$ ). Taking into account that leaves are the parts of plants that perform three important functions (photosynthesis, transpiration and gas exchange) higher abundance in total phenols and flavonoids in the leaves extracts than in root or fruit extracts could be expected. Likewise, it should take into account that in various plants, polyphenols are synthesized in different plant parts and then translocated, to be accumulated in other places. For example, some plants produce polyphenols in roots to be stored in flowers or some other parts. ${ }^{42}$ However, it is evident that all three examined extracts are rich in polyphenols.

In the study conducted by Topuzovic et al. ${ }^{15}$ it was reported that concentration of phenols in Sambucus ebulus extracts obtained by using solvents of high polarity is low, while less polar solvents produced extracts rich with polyphenols. In that sense, SCW offers possibilities for fine tuning its polarity by varying operational parameters during extraction. Moreover, in the case of bioactive molecules, carefully balanced moderate hydrolytical potential of superheated water may be successfully exploited.

For deeper analysis of polyphenolic composition HPLC analysis was performed, and results obtained are presented in Table 1. Phenolic compounds were identified by matching their retention times and ultraviolet spectra with those of standards. The content of polyphenols was calculated by using concentrations obtained from calibration curves of each polyphenolic compound standard and expressed as milligrams per liter of liquid extract $\left(\mathrm{mg} \mathrm{L}^{-1}\right)$.

The total phenolics content was higher than the sum of individual phenolics identified using HPLC. This difference can be explained by the fact that the Folin-Ciocalteu method is not selective and not an absolute measure of the amount of phenolics compounds. Different substances (organic acids, sugars, amino acids, proteins and other hydrophilic compounds) are reported to interfere with this assay. ${ }^{43}$ However, HPLC analysis showed that leaves extracts contain the most polyhenolic substances, which matches with the results obtained by the above mentioned spectrophotometric method.

As can be seen in Table 1 the largest number of detected compounds are phenolic acids, the most dominant being gallic acid with concentration in the range $141.35 \mathrm{mg} \mathrm{L}^{-1}$ to $868.98 \mathrm{mg} \mathrm{L}^{-1}$, a much higher content than all other detected components. Nine of ten different phenolic acids were detected, with the absence of only vanillic acid. According to our preliminary investigation, for vanillic acid isolation the use of modifier is required. For example, extraction of this acid is more efficient with $0.05 \mathrm{~mol} \mathrm{~L}^{-1}$ hydrochloric acid as modifier. ${ }^{44}$ Apart from that, the presence of 
Table 1. Detected phenolic compounds and its content $\left(\mathrm{mg} \mathrm{L}^{-1}\right)$ in observed Sambucus ebulus L. subcritical water extracts

\begin{tabular}{lccc} 
Compound & Root & Leaf & Fruit \\
\hline Gallic acid & 208.84 & 141.35 & 868.98 \\
Protocatechuic acid & 12.23 & 19.56 & 39.16 \\
Catechin & 55.98 & 16.20 & nd \\
Chlorogenic acid & 5.96 & 274.69 & 36.82 \\
Vanillic acid & nd $^{*}$ & nd & nd \\
Caffeic acid & 4.28 & 128.88 & 17.21 \\
Epicatechin & $<\mathrm{LOQ}^{* *}(1.49)$ & $<\mathrm{LOQ}(1.46)$ & $<\mathrm{LOQ}(0.94)$ \\
Syringic acid & $\mathrm{nd}$ & $<\mathrm{LOQ}(3.60)$ & $\mathrm{nd}$ \\
$p$-Coumaric acid & $<\mathrm{LOQ}(2.21)$ & 4.66 & $<\mathrm{LOQ}(1.29)$ \\
Ferulic acid & $<\mathrm{LOQ}(2.36)$ & $<\mathrm{LOQ}(1.79)$ & 3.38 \\
Sinapic acid & $<\mathrm{LOD} * * *(1.47)$ & $<\mathrm{LOD}(0.84)$ & $<\mathrm{LOD}(0.49)$ \\
Naringin & 1.82 & 5.31 & 1.97 \\
Rutin & nd & 24.37 & 6.53 \\
Cinnamic acid & nd & 2.44 & $\mathrm{nd}$ \\
Naringenin & nd & nd & nd \\
Quercetin & nd & $<\mathrm{LOQ}(2.33)$ & $<\mathrm{LOD}(1.24)$
\end{tabular}

${ }^{*}$ nd - not detected; **LOQ - limit of quantification; ${ }^{* * *}$ LOD - limit of detection.

other polyphenolic structures was noted in the extract. However, some other compounds, like naringenin, were not detected. Taking into account that this flavonoid has a structure of aglycones it is assumed that much higher temperature could be more appropriate for its extraction. According to the reported data naringenin could be extracted at high temperatures, close to $170{ }^{\circ} \mathrm{C} .{ }^{16}$ The same situation is observed in the case of quercetin. This flavonol with $\mathrm{OH}$ group in a side chain is efficiently extracted at $170^{\circ} \mathrm{C}$ as well. ${ }^{16}$ In our study, a much lower temperature was used for the extraction process. Although the absence of naringenin was recorded, its glucoside (naringin) was identified in all three extracts examined $\left(1.82-5.31 \mathrm{mg} \mathrm{L}^{-1}\right)$. This correlates with the fact that aglycone forms of flavonoids are stable at high extraction temperatures in subcritical water. This implies that much higher temperatures are required for its extraction, but bound forms can be well extracted at lower temperatures, such as in this case.

\section{Antioxidant activity}

Antioxidant activity of Sambucus ebulus roots, leaves and fruits subcritical extracts was evaluated by using two different antioxidant assays: reducing power and DPPH tests. The results obtained, expressed as $I C_{50}$ values, are presented in Fig. 2 . The results represent mean values of triplicates $\pm S D$.

In the reducing power assay, all examined extracts showed high ability to reduce $\mathrm{Fe}^{+3}$ to $\mathrm{Fe}^{+2}$. Nevertheless, the most potent extracts were found to be those obtained from Sambucus ebulus leaves $\left(0.15 \mathrm{mg} \mathrm{mL}^{-1}\right)$ in comparison with others obtained from fruits $\left(0.24 \mathrm{mg} \mathrm{mL}^{-1}\right)$ and roots $\left(0.31 \mathrm{mg} \mathrm{mL}^{-1}\right)$ (Fig. 2). Such results were in concordance with previously determined total phenols and flavonoids content and antioxidant ability related or at least partly explicable by the high content of this group of secondary metabolites in the samples.

In a DPPH test (Fig. 2), the $I_{50}$ values for Sambucus ebulus extracts varied from 0.056 to $0.081 \mathrm{mg} \mathrm{mL}^{-1}$, which indicates that all investigated extracts showed good scavenging activity for DPPH radicals. The highest scavenging capacity was expressed by leaves extract. The concentration of $0.056 \mathrm{mg} \mathrm{mL}^{-1}$ was sufficient

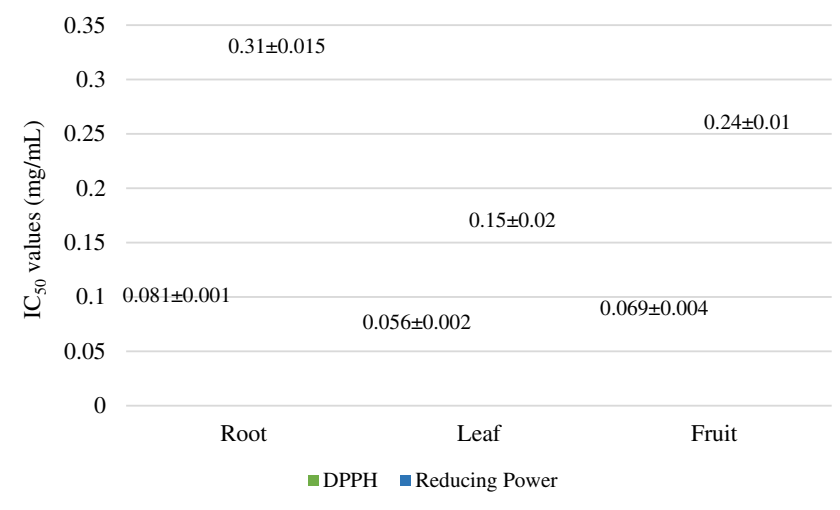

Figure 2. Antioxidant activity of Sambucus ebulus L. extracts.

Table 2. Cytotoxic activity of Sambucus ebulus L. roots, leaves and fruits subcritical water extract

\begin{tabular}{lccc} 
& \multicolumn{3}{c}{$\mathrm{IC}_{50}$ values $\left(\mu \mathrm{g} \mathrm{mL}^{-1}\right)$} \\
\cline { 2 - 4 } Sample & HeLa & A549 & LS174T \\
\hline Root & $2.86 \pm 0.11$ & $4.42 \pm 1.77$ & $8.10 \pm 2.09$ \\
Leaf & $0.58 \pm 0.18$ & $0.76 \pm 0.11$ & $1.89 \pm 0.49$ \\
Fruit & $1.03 \pm 0.00$ & $2.85 \pm 1.00$ & $1.89 \pm 0.20$ \\
\hline
\end{tabular}

${ }^{*} \mathrm{C}_{50}$ is defined as the extract concentration that results in $50 \%$ cell growth inhibition.

to reduce radical concentration to $50 \%$. The result revealed very good antiradical activity. However, in these tests, extracts prepared from roots exhibited the lowest free radical scavenging capacity $\left(0.081 \mathrm{mg} \mathrm{mL}^{-1}\right)$. Nevertheless, the results obtained still represent very high scavenging properties.

The two antioxidant methods applied, which involve different mechanisms, clearly showed quite high antioxidant potential of this plant. Although different studies have reported the antioxidant activity of this plant, there is no data concerning its SCW extracts. In comparison with a study conducted by Mozaffari et al. ${ }^{45}$ ethanolic extracts of Sambucus ebulus obtained by Soxhlet, was able to neutralize $49.16 \%$ of DPPH radicals at a concentration of $400 \mathrm{mg} \mathrm{mL}^{-1}$. Ebrahimzadeh et al. ${ }^{46}$ reported that aqueous extract exhibits higher DPPH radical-scavenging activity $\left(I C_{50}=202.50 \mathrm{mg} \mathrm{mL}^{-1}\right)$ than methanol extract $\left(\mathrm{IC}_{50}=723.62 \mathrm{mg}\right.$ $\left.\mathrm{mL}^{-1}\right)$. When reduction power ability is concerned, there are some published data which suggest a weak $\mathrm{Fe}^{3+}$ reducing ability at $25-800 \mathrm{mg} \mathrm{mL}^{-1} .46$

\section{Cytotoxic activity}

In this study the cytotoxic activity of Sambucus ebulus extracts was evaluated in a panel of three different cell lines. Antiproliferative activity was explored with the extracts concentrations in the range 0.05 to $4.17 \mu \mathrm{g} \mathrm{mL}^{-1}$ in the case of leaves and fruit extracts, and in the range 0.05 to $16.67 \mu \mathrm{g} \mathrm{mL}^{-1}$ in the case of roots extract. Treatment of three cell lines with Sambucus ebulus extracts resulted in a considerable dose-dependent cytotoxicity, where HeLa cells were the most sensitive to all examined extracts. Examined cytotoxic activities of observed extracts were investigated as $I C_{50}$ values (Table 2).

The greatest potential to affect cell survival was shown by extract obtained from leaves. Leaves extract exerted survival inhibition of HeLa, A549 and LS 174 T cell lines by $50 \%$ at lower concentrations 
than root or fruit extracts. This suggests that this extract is more cytotoxic towards test cancer cells. On the other hand, root extracts had the lowest cytotoxic potential.

The protocol of the American National Cancer Institute recommends that $\mathrm{IC}_{50}<30 \mu \mathrm{g} \mathrm{mL}^{-1} 47$ should be considered significant for extracts of plant origin, and our results demonstrated that tested SCW extracts from Sambucus ebulus have significant cytotoxic activity against all three cancer cell lines.

The results obtained, in terms of cytotoxic activity of Sambucus ebulus extracts, were in accordance with total phenols and flavonoids contents. However, it is assumed that the additive and synergistic effects of phytochemicals in plant are responsible for their potent anticancer activity and that the benefits of this diet are attributed to the complex mixture of phytochemicals present in whole foods. ${ }^{48}$ Due to excellent solvating properties, subcritical water is a medium able to extract compounds of different polarities. Thus, the composition of SCW extracts is complex containing a great number of compounds belonging to different chemical classes and of different polarities. Diversity of the composition of Sambucus ebulus SCW extracts supports the fact that this extract is a rich source of potent phytochemicals with great potential in food and pharmaceutical industries.

\section{Inhibitory activity on $\alpha$-amylase, $\alpha$-glucosidase and tyrosinase}

Diabetes mellitus (DM) is one of the most common types of metabolic syndrome and the prevalence of it is increasing day by day. According to several reports, DM affected about 300 million people in 2010. It is estimated that there will be about 439 million DM patients in the world by $2030 .{ }^{49}$ At this point, new strategies are of obvious importance for managing DM. The key enzyme inhibition theory could be considered as one of the most effective approaches. According to this theory, the inhibition of carbohydrate digestive enzymes ( $\alpha$-amylase and $\alpha$-glucosidase) is important to control postprandial blood glucose level in DM. The enzyme catalyzes the hydrolysis of $\alpha(1,4)$ glycoside bonds in carbohydrates resulting in free glucose. At this point, several synthetic inhibitors (acarbose, viglibose or miglitol) are available in the world market. ${ }^{50,51}$ However, there are several side effects, such as gastrointestinal disturbances or abdominal pain ${ }^{52,53}$ which should not be neglected. From this point of view, naturally-occurring inhibitors are important, as powerful and safe antidiabetic agents with perspective in designing new antidiabetic drugs.

We tested $\alpha$-amylase and $\alpha$-glucosidase inhibitory effects of Sambucus ebulus extracts and the results obtained are shown in Table 3. The extract from leaves exhibited the strongest $\alpha$-glucosidase effects with $2.04 \mathrm{mmol}$ ACE $\mathrm{g}^{-1}$ extract, followed
Table 3. Enzyme inhibitory activity of Sambucus ebulus L. roots, leaves and fruits subcritical water extract

\begin{tabular}{lccc} 
Sample & $\begin{array}{c}\alpha \text {-Amylase } \\
\text { inhibiton } \\
\left(\begin{array}{c}\text { mmol ACE } \\
\text { extract })\end{array}\right.\end{array}$ & $\begin{array}{c}\alpha \text { - Glucosidase } \\
\text { inhibition } \\
\left(\text { mmol ACE* }^{-1}\right. \\
\text { extract })\end{array}$ & $\begin{array}{c}\text { Tyrosinase } \\
\text { inhibition } \\
\left(\text { mg KAEs }^{* *} \mathrm{~g}^{-1}\right. \\
\text { extract })\end{array}$ \\
\hline Root & $0.48 \pm 0.02$ & $0.37 \pm 0.11$ & $9.32 \pm 0.55$ \\
Leaf & $0.42 \pm 0.02$ & $2.04 \pm 0.05$ & $19.67 \pm 5.26$ \\
Fruit & $0.45 \pm 0.01$ & $1.40 \pm 0.15$ & $10.94 \pm 0.89$ \\
\hline
\end{tabular}

*ACE - acarbose equivalent. **KAE - kojic acid equivalent.

by fruit $\left(1.40 \mathrm{mmol} \mathrm{ACE} \mathrm{g}^{-1}\right.$ extract $)$ and root $\left(0.37 \mathrm{mmol} \mathrm{ACE} \mathrm{g}^{-1}\right.$ extract). The strongest activity for leaves may be explained by the higher concentration of phenolics in the extract. This is in accordance with results of several authors who reported a linear correlation of $\alpha$-glucosidase inhibitory effects with phenolics composition. ${ }^{54-56}$ Moreover, the extract from leaves had very high concentrations of chlorogenic and caffeic acids and they were reported, by some researchers, as antidiabetic agents. ${ }^{57,58} \mathrm{How}$ ever, the roots extract was the most active with $0.48 \mathrm{mmol} \mathrm{ACE} \mathrm{g}^{-1}$ extracts, close to of fruits $\left(0.45 \mathrm{mmol}^{\mathrm{ACE} \mathrm{g}} \mathrm{g}^{-1}\right.$ extract). The extract from leaves was the less effective on $\alpha$-amylase with $0.42 \mathrm{mmol}$ ACE $g^{-1}$ extract. The observed differences could be explained by the concentration levels of gallic acid in extracts. Fruits and roots extracts contain higher concentrations of gallic acid compared with extracts from leaves. Those findings are supported by some authors, who reported that gallic acid is an important agent for $\alpha$-amylase. ${ }^{59,60}$

Tyrosinase is a copper-containing enzyme and plays a key role in the synthesis of melanin. At this point, the inhibition of tyrosinase is considered an effective therapeutic tool for pigmentation disorders. ${ }^{61}$ Thus, some compounds such as kojic acid and arbutin are chemically developed as anti-pigmentation agents. However, these compounds may show undesirable side effects, such as toxicity and low stability. ${ }^{62,63}$ In this sense, additional investigation of natural and safe tyrosinase inhibitory agents is required. The inhibitory effect of Sambucus ebulus extracts on tyrosinase is depicted in Table 3. As can be seen, the extract from leaves was the most potent with $19.67 \mathrm{mg} \mathrm{KAE} \mathrm{g}^{-1}$ extract, followed by fruits (10.94 $\mathrm{mg} \mathrm{KAE} \mathrm{g}^{-1}$ extract) and roots ( $9.32 \mathrm{mg} \mathrm{KAE}$ $\mathrm{g}^{-1}$ extract). It appears that the presence of phenolic compounds in the extract from leaves might contribute to the inhibition of tyrosinase. Also, the extract contained higher concentrations of chlorogenic and caffeic acids, identified as anti-tyrosinase

Table 4. Correlation of total phenols and total flavonoids content with inhibitory concentrations obtained in different biological activity assays

\begin{tabular}{|c|c|c|c|c|c|c|c|}
\hline Parameter & $\mathrm{TP}$ & TF & $I C_{50 \text { (reducing power) }}$ & $\mathrm{IC}_{50(\mathrm{DPPH})}$ & $I C_{50(A 549)}$ & $\mathrm{IC}_{50(\mathrm{LS} 174 \mathrm{~T})}$ & $\mathrm{IC}_{50 \text { (HeLa) }}$ \\
\hline TP & 1 & & & & & & \\
\hline TF & 0.9564 & 1 & & & & & \\
\hline Red & $-0.9999^{a}$ & -0.9608 & 1 & & & & \\
\hline DPPH & $-0.9994^{b}$ & -0.9461 & $0.9988^{b}$ & 1 & & & \\
\hline$I C_{50(A 549)}$ & $-0.9997^{b}$ & -0.9634 & $0.9999^{a}$ & $0.9983^{b}$ & 1 & & \\
\hline$I C_{50(\mathrm{LS} 174 \mathrm{~T})}$ & -0.8362 & -0.6397 & 0.8278 & 0.8542 & 0.8222 & 1 & \\
\hline$I C_{50(\text { HeLa })}$ & -0.9238 & -0.7717 & 0.9178 & 0.9361 & 0.9139 & 0.9825 & 1 \\
\hline
\end{tabular}

a statistically significant at $P<0.01$, b statistically significant at $P<0.05$; TP-total phenols; TF-total flavonoids. 
agents in several studies..$^{61,64-66}$ To the best of our knowledge, the present work is the first study on enzyme inhibitory properties of Sambucus ebulus, which could be considered a valuable source (naturally-occurring enzyme inhibitory agents) for developing new phyto-pharmaceuticals and food supplements.

\section{Correlation analysis}

In order to determine the relative importance of the various classes of phenolic compounds in biological activity, a correlation analyses was conducted. The results obtained are given in the Table 4.

Pearson's correlation coefficients between TP and other tested parameters were particularly high $(r>0.9)$, with the exception of correlation between TP and IC $C_{50(L S ~ 174 T)}(r=0.8362)$. TF also showed high correlation with $I C_{50 \text { (reducing power) }}, I C_{50(\mathrm{DPPH})}$ and $I \mathrm{C}_{50(\mathrm{~A} 549)}$, while correlation between TF and IC $\mathrm{C}_{50 \text { (LS 174T) }}(r=0.6397)$ and IC $\mathrm{C}_{50 \text { (HeLa) }}$ $(r=0.7717)$ were good. Correlation between $\mathrm{IC}_{50 \text { (reducing power) }}$ $I C_{50(\mathrm{DPPH})}, I \mathrm{C}_{50(\mathrm{~A} 549)}$ and IC $\mathrm{C}_{50(\mathrm{LS} \mathrm{174T)}}$ were high ( $\left.r>0.8\right)$. Such coefficients may indicate that detected compounds were responsible for biological activity detected using different in vitro assays. On the other hand, lower correlation among TF and IC $\mathrm{C}_{50 \text { (LS 174T) }}$ and $\mathrm{IC}_{50 \text { (HeLa) }}$ indicated that flavonoid compounds may be only partially responsible for the detected activity.

\section{CONCLUSION}

In this work, subcritical water extracts obtained from Sambucus ebulus L. parts (leaves, roots and fruits) were investigated for biological and chemical fingerprints for the first time. Our results showed that Sambucus ebulus extracts have remarkable biological activities. Generally, the leaves exhibited stronger biological activities than roots and fruits. Also, these plant extracts have important bioactive compounds including gallic acid, catechin and chlorogenic acid. Extraction is a crucial step in the preparation of plant products. At this point, subcritical water extraction could be considered a novel non-toxic and green procedure. The subcritical water extracts obtained from Sambucus ebulus may be used as a source of bioactive compounds for designing new biological formulations including pharmaceuticals and functional food ingredients.

\section{ACKNOWLEDGEMENT}

The present work is part of the research conducted within the bilateral cooperation between the Republic of Serbia and Portuguese Republic (Project No. 451-03-01765/2014-09/28) and within the projects of the Serbian Ministry of Education, Science and Technological Development, (Projects No. TR31013, III43009 and 175011). Manuela M. Moreira (SFRH/BPD/97049/2013) is grateful for the postdoctoral fellowships financed by POPH-QREN - Tipologia 4.1 - Formação Avançada, subsidized by Fundo Social Europeu and Ministério da Ciência, Tecnologia e Ensino Superior. The authors are also grateful for the financial support from FCT/MEC through national funds and co-financed by FEDER, under the Partnership Agreement PT2020 through the project UID/ QUI/50006/2013 $\mathrm{POCI} / 01 / 0145 /$ FERDER/007265.

\section{CONFLICT OF INTEREST}

We wish to confirm that there are no known conflicts of interest associated with this publication and there has been no significant financial support for this work that could have influenced its outcome.

\section{REFERENCES}

1 Panda H, Cultivation and Utilization of Aromatic Plants. Asia Pacific Business Press Inc. (2005).

2 Ebrahimzadeh M, Mahmoudi M, Saiednia S, Pourmorad F and Salimi E, Anti-inflammatory and anti-nociceptive properties of fractionated extracts in different parts of Sambucus ebulus. JMazandaran Uni Med Sci 16:35-47 (2006).

3 Ebrahimzadeh MA, Mahmoudi M, Karami M, Saeedi S, Ahmadi AH and Salimi E, Separation of active and toxic portions in Sambucus ebulus. Pakistan J Biol Sci PJBS 10:4171-4173 (2007).

4 Guarrera PM, Traditional antihelmintic, antiparasitic and repellent uses of plants in Central Italy. J Ethnopharmacol 68:183-192 (1999).

5 Saeedi Saravi S and Shokrzadeh M, Histopathological and biochemical disorders following administration of Sambucus ebulus extract on mice and rats and preventive effects of vitamins $C$ and $E$ on renal and hepatic disorders. Phcog Mag 5:131-135 (2008).

6 Tuzlacı E and Tolon E, Turkish folk medicinal plants, part III: Şile (İstanbul). Fitoterapia 71:673-685 (2000).

7 Yeşilada $E$, Gürbüz II and Shibata $H$, Screening of Turkish anti-ulcerogenic folk remedies for anti-Helicobacter pylori activity. J Ethnopharmacol 66:289-293 (1999).

8 Süntar IP, Akkol EK, Yalçın FN, Koca U, Keleş H and Yesilada E, Wound healing potential of Sambucus ebulus L. leaves and isolation of an active component, quercetin 3-O-glucoside. J Ethnopharmacol 129:106-114 (2010).

9 Kiselova Y, Ivanova D, Chervenkov T, Gerova D, Galunska B and Yankova T, Correlation between the in vitro antioxidant activity and polyphenol content of aqueous extracts from bulgarian herbs. Phytotherapy Res 20:961-965 (2006).

10 Liener IE, Implications of antinutritional components in soybean foods. Crit Rev Food Sci Nutrit 34:31 - 67 (1994).

11 Stirpe F and Battelli MG, Ribosome-inactivating proteins: progress and problems. Cell Mol Life Sci 63:1850-1866 (2006).

12 Jimenez P, Cabrero P, Basterrechea JE, Tejero J, Cordoba-Diaz D, Cordoba-Diaz M et al., Effects of short-term heating on total polyphenols, anthocyanins, antioxidant activity and lectins of different parts of dwarf elder (Sambucus ebulus L.). Plant Foods Human Nutr 69:168-174 (2014).

13 Feizbakhsh A, Pazoki $H$ and MA E, Sambucus ebulus, introduction to mechanism of action; a chemical viewpoint. Pharmacol Online 1:16-22 (2010).

14 Miser-Salihoglu E, Akaydin G, Caliskan-Can E and Yardim-Akaydin S, Evalution of antioxidant activity of various herbal folk medicines. Nutr Food Sci 3:1 - 9 (2013).

15 Topuzovic MD, Stankovic MS, Jakovljevic DZ and Bojovic BM, Plant part variability of Sambucus ebulus L. secondary metabolites content and antioxidant activity. Agro Food Ind Hi Technol 27:2 (2016).

16 Plaza M and Turner C, Pressurized hot water extraction of bioactives. TrAC Trends Analyt Chem 71:39-54 (2015).

17 Möckel H, Welter G and Melzer H, Correlation between reversed-phase retention and solute molecular surface type and area: I. Theoretical outlines and retention of various hydrocarbon classes. J Chromatogr A 388:255-266 (1987).

18 Mustafa A and Turner C, Pressurized liquid extraction as a green approach in food and herbal plants extraction: a review. Analytica Chimica Acta 703:8-18 (2011).

19 Perry RH and Green D, Perry's Chemical Engineers' Handbook, 6th edn. McGraw-Hill, New York (1984).

20 Richter BE, Jones BA, Ezzell JL, Porter NL, Avdalovic N and Pohl C, Accelerated solvent extraction: a technique for sample preparation. Anal Chem 68:1033-1039 (1996).

21 Švarc-Gajić J, Sampling and Sample Preparation in Analytical Chemistry. Nova Science Publishers, New York (2012).

22 Wang R, Neoh TL, Kobayashi T and Adachi S, Antioxidative capacity of the degradation products of glucuronic and galacturonic acid from subcritical water treatment. Chem Eng Technol 34:1514-1520 (2011).

23 Khuwijitjaru P, Suaylam B and Adachi S, Degradation of caffeic acid in subcritical water and online HPLC-DPPH assay of degradation products. J Agric Food Chem 62:1945-1949 (2014). 
24 Khuwijitjaru P, Plernjit J, Suaylam B, Samuhaseneetoo S, Pongsawatmanit $\mathrm{R}$ and Adachi $\mathrm{S}$, Degradation kinetics of some phenolic compounds in subcritical water and radical scavenging activity of their degradation products. Canadian J Chem Eng 92:810-815 (2014).

25 Cvetanović A, Švarc-Gajić J, Gašić U, Tešić Ž, Zengin G, Zeković $Z$ et al., Isolation of apigenin from subcritical water extracts: optimization of the process. J Supercrit Fluids 120:32-42 (2017).

26 Kähkönen MP, Hopia Al, Vuorela HJ, Rauha J-P, Pihlaja K, Kujala TS et al., Antioxidant activity of plant extracts containing phenolic compounds. J Agric Food Chem 47:3954-3962 (1999).

27 Singleton V and Rossi JA, Colorimetry of total phenolics with phosphomolybdic-phosphotungstic acid reagents. Am J Enol Viticulture 16:144-158 (1965).

28 Markham KR, Flavones, flavonols and their glycosides. Methods Plant Biochem 1:197-235 (1989).

29 Rubilar M, Pinelo M, Shene C, Sineiro J and Nuñez MJ, Separation and HPLC-MS identification of phenolic antioxidants from agricultural residues: almond hulls and grape pomace. J Agric Food Chem 55:10101-10109 (2007).

30 Espín JC, Soler-Rivas C and Wichers HJ, Characterization of the total free radical scavenger capacity of vegetable oils and oil fractions using 2, 2-diphenyl-1-picrylhydrazyl radical. J Agric Food Chem 48:648-656 (2000).

31 Oyaizu M, Studies on products of browning reaction. Japanese J Nutrit Dietet 44:307-315 (1986).

32 Matić IZ, Aljančić I, Žižak Ž, Vajs V, Jadranin M, Milosavljević S et al., In vitro antitumor actions of extracts from endemic plant Helichrysum zivojinii. BMC Complement Alternat Med 13:36 (2013).

33 Mosmann T, Rapid colorimetric assay for cellular growth and survival: application to proliferation and cytotoxicity assays. J Immunolog Methods 65:55-63 (1983).

34 Ohno M and Abe T, Rapid colorimetric assay for the quantification of leukemia inhibitory factor (LIF) and interleukin-6 (IL-6). J Immunolog Methods 145:199-203 (1991).

35 Zengin G, Sarikurkcu C, Aktumsek A, Ceylan R and Ceylan O, A comprehensive study on phytochemical characterization of Haplophyllum myrtifolium Boiss. endemic to Turkey and its inhibitory potential against key enzymes involved in Alzheimer, skin diseases and type II diabetes. Ind Crops Prod 53:244-251 (2014).

36 Orhan IE, Senol FS, Gulpinar AR, Sekeroglu N, Kartal M and Sener $B$, Neuroprotective potential of some terebinth coffee brands and the unprocessed fruits of Pistacia terebinthus $\mathrm{L}$. and their fatty and essential oil analyses. Food Chem 130:882-888 (2012).

37 Rice-Evans CA, Miller NJ and Paganga G, Structure-antioxidant activity relationships of flavonoids and phenolic acids. Free Radical Biol Med 20:933-956 (1996).

38 Arts IC and Hollman PC, Polyphenols and disease risk in epidemiologic studies. Am J Clinic Nutrit 81:317S-325S (2005).

39 Graf BA, Milbury PE and Blumberg JB, Flavonols, flavones, flavanones, and human health: epidemiological evidence. J Med Food 8:281-290 (2005)

40 Pandey KB and Rizvi SI, Plant polyphenols as dietary antioxidants in human health and disease. Oxidat Med Cellul Longevity 2:270-278 (2009).

41 Akula R and Ravishankar GA, Influence of abiotic stress signals on secondary metabolites in plants. Plant Signal Behavior 6:1720-1731 (2011).

42 Šamec D, Phytochemical and genetic investigation of endemic species Teucrium arduini, Moltkia petraea, Micromeria croatica and Rhamnus intermedia. Sveučilišni poslijediplomski interdisciplinarni doktorski studij Molekularne bioznanosti, Sveučilište Josipa Jurja Strossmayera u Osijeku (2013).

43 Vulić J, Čanadanović-Brunet J, Ćetković G, Tumbas V, Djilas S, Četojević-Simin D et al., Antioxidant and cell growth activities of beet root pomace extracts. J Function Foods 4:670-678 (2012)

44 Cvetanović A, Optimization of novel extraction techniques for apigenin isolation from chamomile flowers (Chamomilla recutita L.) and characterization of biological activity of obtained extracts. University of Novi Sad. (2016).
45 Mozaffari S, Lahooti M and Larijani K, Total phenolic, flavonoid content and radical scavenging activity of Sambucus ebulus L. from Iran. Int J Res Pharm Pharmaceut Sci 1:36-38 (2016).

46 Ebrahimzadeh MA, Ehsanifar S and Eslami B, Sambucus ebulus elburensis fruits: a good source for antioxidants. Pharmacognosy Mag 5:213 (2009).

47 Suffness $M$ and Pezzuto JM, Assays related to cancer drug discovery. Methods Plant Biochem: Assays Bioactiv 6:71-133 (1990).

$48 \mathrm{Liu} \mathrm{RH}$, Health benefits of fruit and vegetables are from additive and synergistic combinations of phytochemicals. Am J Clinic Nutrit 78:517S-520S (2003).

49 Shaw JE, Sicree RA and Zimmet PZ, Global estimates of the prevalence of diabetes for 2010 and 2030. Diabetes Res Clinic Practice 87:4-14 (2010).

50 Dong H-Q, Li M, Zhu F, Liu F-L and Huang J-B, Inhibitory potential of trilobatin from Lithocarpus polystachyus Rehd against $\alpha$-glucosidase and $\alpha$-amylase linked to type 2 diabetes. Food Chem 130:261-266 (2012).

51 Etxeberria U, de la Garza AL, Campión J, Martinez JA and Milagro $\mathrm{Fl}$, Antidiabetic effects of natural plant extracts via inhibition of carbohydrate hydrolysis enzymes with emphasis on pancreatic alpha amylase. Expert Opin Therapeut Targets 16:269-297 (2012).

52 Buchholz T and Melzig MF, Medicinal plants traditionally used for treatment of obesity and diabetes mellitus - screening for pancreatic lipase and $\alpha$-amylase inhibition. Phytotherapy Res 30:260-266 (2016).

53 Chiasson J-L, Josse RG, Gomis R, Hanefeld M, Karasik A, Laakso M et al., Acarbose for prevention of type 2 diabetes mellitus: the STOP-NIDDM randomised trial. Lancet 359:2072-2077 (2002).

54 Dewi RT and Maryani F, Antioxidant and $\alpha$-glucosidase inhibitory compounds of Centella Asiatica. Procedia Chem 17:147-152 (2015).

55 Hemalatha P, Bomzan DP, Rao BS and Sreerama YN, Distribution of phenolic antioxidants in whole and milled fractions of quinoa and their inhibitory effects on $\alpha$-amylase and $\alpha$-glucosidase activities. Food Chem 199:330-338 (2016).

56 Wang T, Li X, Zhou B, Li H, Zeng J and Gao W, Anti-diabetic activity in type 2 diabetic mice and $\alpha$-glucosidase inhibitory, antioxidant and anti-inflammatory potential of chemically profiled pear peel and pulp extracts (Pyrus spp.). J Function Foods 13:276-288 (2015).

57 Oboh G, Agunloye OM, Adefegha SA, Akinyemi AJ and Ademiluyi $\mathrm{AO}$, Caffeic and chlorogenic acids inhibit key enzymes linked to type 2 diabetes (in vitro): a comparative study. J Basic Clinic Physiol Pharmacol 26:165-170 (2015).

58 Rohn S, Rawel HM and Kroll J, Inhibitory effects of plant phenols on the activity of selected enzymes. J Agricult Food Chem 50:3566-3571 (2002).

59 Oboh G, Ogunsuyi OB, Ogunbadejo MD and Adefegha SA, Influence of gallic acid on $\alpha$-amylase and $\alpha$-glucosidase inhibitory properties of acarbose. J Food Drug Anal 24:627-634 (2016).

60 Punithavathi VR, Prince PSM, Kumar R and Selvakumari J, Antihyperglycaemic, antilipid peroxidative and antioxidant effects of gallic acid on streptozotocin induced diabetic Wistar rats. Eur JPharmacol 650:465-471 (2011).

$61 \mathrm{Kim} \mathrm{Y-J} \mathrm{and} \mathrm{Uyama} \mathrm{H,} \mathrm{Tyrosinase} \mathrm{inhibitors} \mathrm{from} \mathrm{natural} \mathrm{and} \mathrm{synthetic}$ sources: structure, inhibition mechanism and perspective for the future. Cellul Molecul Life Sci 62:1707-1723 (2005).

62 Baek HS, Hong YD, Lee CS, Rho HS, Shin SS, Park Y-H et al., Adamantyl N-benzylbenzamide: new series of depigmentation agents with tyrosinase inhibitory activity. Bioorgan Med Chem Lett 22:2110-2113 (2012).

63 Karioti A, Protopappa A, Megoulas N and Skaltsa H, Identification of tyrosinase inhibitors from Marrubium velutinum and Marrubium cylleneum. Bioorgan Med Chem 15:2708-2714 (2007).

64 Ado MA, Abas F, Leong SW, Shaari K, Ismail IS, Ghazali HM et al, Chemical constituents and biological activities of Callicarpa maingayi leaves. South African J Botany 104:98-104 (2016).

65 Erdem SA, Senol FS, Budakoglu E, Orhan IE and Sener B, Exploring in vitro neurobiological effects and high-pressure liquid chromatography-assisted quantitation of chlorogenic acid in 18 Turkish coffee brands. J Food Drug Anal 24:112-120 (2016).

66 Li H-R, Habasi M, Xie L-Z and Aisa HA, Effect of chlorogenic acid on melanogenesis of B16 melanoma cells. Molecules 19:12940-12948 (2014). 